\title{
Clinical and post mortem examination of white worm lizards (Amphisbaena alba) in the State of Paraíba, Northeastern Brazil: morphological, pathological and radiographic findings of a secretive species ${ }^{1}$
}

\author{
Raquel M.F. Pereira ${ }^{2}$ (D) Raquel A.F. Silva ${ }^{3}$, Rubia A.G. Sampaio ${ }^{4}$, José F. Silva Neto ${ }^{3}$, \\ Rafael L. Oliveira ${ }^{4}$, Carolina F. Pires ${ }^{4}$, Andressa D.A. Frade ${ }^{4}$, Jeann Leal de Araújo ${ }^{4 *}$ (D)
}

\begin{abstract}
Pereira R.M.F., Silva R.A.F., Sampaio R.A.G., Silva Neto J.F., Oliveira R.L., Pires C.F., Frade A.D.A. \& Leal de Araújo J. 2021. Clinical and post mortem examination of white worm lizards (Amphisbaena alba) in the State of Paraíba, Northeastern Brazil: morphological, pathological and radiographic findings of a secretive species. Pesquisa Veterinária Brasileira 41:e06832, 2021. Hospital Veterinário, Departamento de Ciências Veterinárias, Centro de Ciências Agrárias, Universidade Federal da Paraíba, Campus II, 12 Rodovia PB-079, Areia, PB 58397-000, Brazil. E-mail: lealjeann@gmail.com

Amphisbenians are limbless reptiles that belong to the order Squamata. Due to their fossorial and secrevie habits, little is known about their morphology, ecology and pathological conditions that may affect them. In this manuscript, we present a brief guide for identification of normal structures as well as traumatic injuries on radiography and necropsy of Amphisbaena alba. From April to September 2019, three cases of A. alba with suspected trauma were referred to the Veterinary Hospital of the Federal University of Paraíba (UFPB). In the clinical evaluation, traumatic injuries were observed, and support therapy was instituted, but they did not resist and died shortly after. Bone fractures and organ ruptures, in addition to specific structures of this species were identified on radiography. A systematic necropsy was performed of all amphisbaenians in order to evaluate external and internal structures, not only to identify lesions but also to investigate the morphological aspects of amphisbenids. Macroscopically, multiple organ fractures and ruptures observed in radiographs were confirmed, in addition to the presence of the cestodes Semenoviella amphisbaenae in the large intestine. Histologically, it was possible to identify normal characteristics and microscopic lesions in the tissues. This is the first study to incorporate morphological, clinical, and pathological aspects of A. alba. This manuscript brings essential information for wildlife veterinarians and pathologists who may have to treat or perform a necropsy on these unique reptiles.
\end{abstract}

INDEX TERMS: White worm lizards, Amphisbaena alba, Brazil, morphology, pathology, radiography, Squamata, reptiles, wildlife diseases, trauma, Semenoviella amphisbaenae, wildlife animals.

RESUMO.- [Exame clínico e post mortem de anfisbenas (Amphisbaena alba) no Estado da Paraíba, Nordeste do Brasil: achados morfológicos, patológicos e radiográficos de uma espécie reservada.] Anfisbenas são répteis desprovidos

\footnotetext{
${ }^{1}$ Received on January 9, 2021.

Accepted for publication on January 26, 2021.

${ }^{2}$ Student, Graduate Program in Veterinary Medicine, Universidade Federal Rural de Pernambuco (UFRPE), Rua Dom Manoel de Medeiros s/n, Dois Irmãos, Recife, PE 52171-900, Brazil.

${ }^{3}$ Student, Graduate Program in Animal Science and Health, Universidade Federal de Campina Grande (UFCG), Av. Universitária s/n, Bairro Santa Cecília, Patos, PB 58708-110, Brazil.

${ }^{4}$ Hospital Veterinário, Departamento de Ciências Veterinárias, Centro de Ciências Agrárias (CCA), Universidade Federal da Paraíba (UFPB), Campus II, 12 Rodovia PB-079, Areia, PB 58397-000, Brazil. *Corresponding author: lealjeann@gmail.com
}

de membros que pertencem a ordem Squamata. Devido a seus hábitos fossoriais e reclusos, pouco se conhece sobre sua morfologia, ecologia e condições patológicas que possam afetálas. Neste artigo, um guia sucinto para a necropsia, identificação de tecidos e órgãos e lesões encontradas em Amphisbaena alba, é apresentado. Durante março e dezembro de 2019, três casos de A. alba com suspeita de trauma foram encaminhados ao Hospital Veterinário da Universidade Federal da Paraíba. $\mathrm{Na}$ avaliação clínica foram observadas lesões traumáticas e instituído um suporte terapêutico, porém não resistiram e morreram em seguida. Foram realizadas projeções radiográficas onde identificaram fraturas e ruptura de órgãos, além de identificar estruturas específicas dessa espécie. Uma avaliação completa de estruturas externas e internas foi conduzida 
para investigar aspectos morfológicos dos anfisbenídeos. Macroscopicamente foram confirmadas múltiplas fraturas e rupturas de órgãos observadas anteriormente nas radiografias, além disso evidenciou no intestino grosso presença de parasitos anoplocéfalos denominados Semenoviella amphisbaenae. $\mathrm{Na}$ histologia foi possível identificar características normais e lesões microscópicas nos tecidos. Esse é o primeiro estudo a incorporar aspectos morfológicos, clínicos e patológicos de $A$. $a l b a$. Esse manuscrito traz informações essenciais para clínicos e patologistas de animais selvagens que podem se deparar com casos clínicos ou de necropsia de Amphisbaena alba.

TERMOS DE INDEXAÇÃO: Anfisbenas, cobra-de-duas-cabeças, Amphisbaena alba, Brasil, morfologia, patologia, radiografia, Squamata, répteis, doenças de vida livre, trauma, anfisbena, Semenoviella amphisbaenae, animais selvagens.

\section{INTRODUCTION}

Amphisbaenians, also known as worm lizards, are limbless squamates of the family Amphisbaenidae (Pinna et al. 2010, Costa \& Bérnils 2018). Although not a member of the suborder Serpentes, these reptiles are popularly known as "two-headed snakes", due to the similar size and morphology of the tail and the head, which are used to confuse a potential predator (Lainson 2003). These highly specialized burrowing reptiles have fossorial habits and are distributed primarily in South America, Caribe, and Sub-Saharan Africa (Teixeira Junior et al. 2019). In Brazil, more than 70 species have been described (Teixeira Junior et al. 2019), many of them in the last decade (Pinna et al. 2010, 2014, Ribeiro et al. 2011, 2015, 2016, 2019, Roberto et al. 2014, Teixeira Junior et al. 2014, Costa et al. 2015, Almeida et al. 2018, Oliveira et al. 2018). Three species, Amphisbaena kiriri, Amphisbaena longinqua and Amphisbaena mongoyo, have been recently described in Northeastern Brazil (Ribeiro et al. 2018, Teixeira Junior et al. 2019).

The white worm-lizard (Amphisbaena alba) is probably the amphisbaenian with the widest geographic distribution of all worm lizards, occurring in most of South America east of the Andes (Colli \& Zamboni 1999). In contrast to some other amphisbaenian species, A. alba lacks caudal autotomy (Colli \& Zamboni 1999). Several characteristics about their biology, anatomy, physiology, and ecology of amphisbaenians are still not well understood, probably due their secretive fossorial habits, which makes the observation of these reptiles in the wild difficult (Kearney 2003). During wildlife rescue programs, amphisbaenians are commonly captured from areas that will be used for the construction of hydroelectric dams or roads (Calixto \& Abrahão Morato 2017). There are no studies on pathology of amphisbaenids.

The aim of this study was to describe morphological and pathological characteristics of three A. alba referred to a Veterinary Hospital in the State of Paraíba, Northeastern Brazil. We provide here a concise illustrated guide to assist wildlife veterinarians and biologists with clinical and postmortem examination of white worm lizards, indicating normal anatomic features and pathological alterations.

\section{CLINICAL DATA}

From April to September 2019, three Amphisbaena alba were found with injuries suggestive of trauma in the city of Areia, State of Paraíba, Northeastern Brazil, and referred to the Veterinary Hospital of the "Universidade Federal da Paraíba" (UFPB). Cases 1 e 2 were found still alive and referred to the Veterinary Hospital for clinical support and submitted to radiographic evaluation but died shortly after. Case 3 was found dead and referred for radiographic examination and sent to the "Laboratório de Patologia Veterinária" of UFPB for necropsy. During the physical examination, the patients weighted between 258g and 280g and it was possible to determine the sex of two cases, one male and one female. Clinically, the animals presented apathy, dehydration, dyspnea, epistaxis and hemoptysis. A therapeutic protocol for traumatic brain injury was instituted in the two amphisbaenians that were alive, but they died shortly afterwards. A summary of the available clinical data for all three cases is found in Table 1.

\section{RADIOLOGICAL FINDINGS}

Dorsoventral and laterolateral radiographies were obtained from all three cases, and allowed the evaluation of the axial skeletal system, the vestigial appendicular skeletal system, and internal organs, especially the cardiorespiratory and digestive tract. The protocol for the radiographic technique used a $43 \mathrm{kVp}$ and a $0,03 \mathrm{mAs}$.

The axial skeleton of the Amphisbaena alba in the observed cases is composed or nearly one hundred and twenty-six vertebrae, where the two first pairs and the 109th and 126th pairs are ribless. In total, it was possible to observe 106 pairs of ribs. The appendicular skeleton of amphisbaenians is rudimentary, and in some cases, absent. The evolution of elongated bodies has close association to the reduction of limbs (Westphal et al. 2019). The remnants of the pectoral and pelvic girdles are represented by cartilaginous rodlike elements and have been described in $A$. alba as paired sigmoidally shaped elements capped distally by small points of cartilage (Kearney 2002). There is conflicting information in the available literature about the presence of pectoral and pelvic girdles in A. alba and some researchers have reported the absence of these structures in the specimens analyzed (Kearney 2002). This discrepancy seems to be related to the methods used to analyze the presence of these structures, once it may not be visible during dissection of specimens. All three cases of the present study presented both pectoral and pelvic girdles, which were readily visible on radiography.

In Case 1 was possible to see anatomical features such as the axial skeleton, trachea, and cardiac silhouette (Fig.1). Additionally, the pulmonary fields consisted of a well-developed

Table 1. Summary of clinical data collected from specimens of Amphisbaena alba referred to UFPB from April to September, 2019

\begin{tabular}{|c|c|c|c|c|c|c|}
\hline Case & Month of arrival & Weight on arrival & Sex & Radriographies & Necropsy & Clinical signs \\
\hline 1 & April/2019 & $258 \mathrm{~g}$ & $\mathrm{~F}$ & $\mathrm{X}$ & $\mathrm{X}$ & Apathy, dehydration and dyspnea. Blood in oral cavity \\
\hline 2 & September/2019 & $265 \mathrm{~g}$ & $\mathrm{~F}$ & $\mathrm{X}$ & $\mathrm{X}$ & Apathy, epistaxis, hemoptysis \\
\hline 3 & September/2019 & $280 \mathrm{~g}$ & M & $\mathrm{X}$ & $\mathrm{X}$ & Dead on arrival. Apparent spinal fracture \\
\hline
\end{tabular}




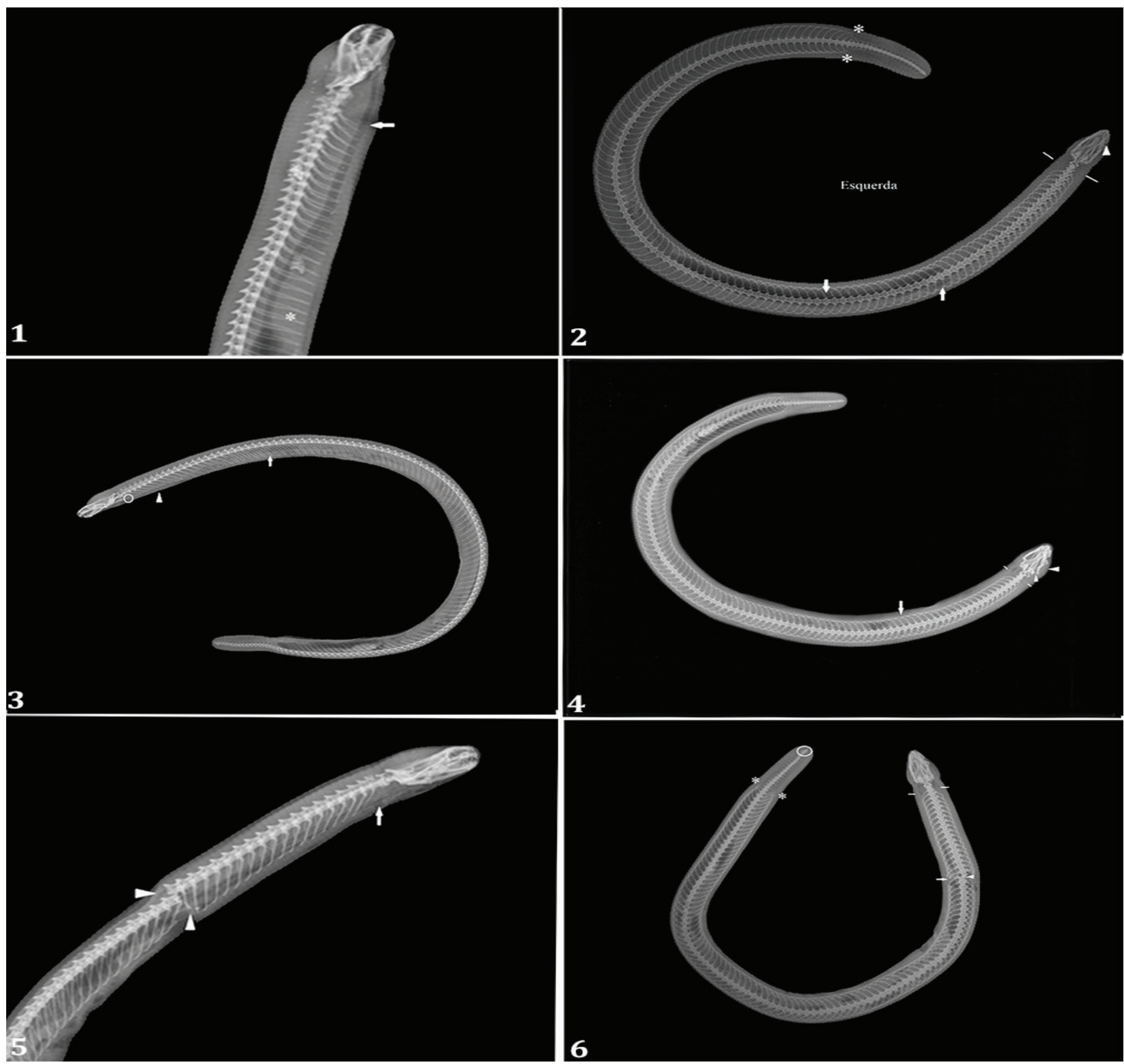

Fig.1-6. Radiological findings in Amphisbaena alba. (1) Laterolateral projection of Case 1. It is possible to view the trachea and cardiac silhouette in the proximal third of the body. (2) Dorsoventral projection of Case 1. It is possible to see all the axial skeleton. Presence of irregularity in the right mandibular branch (arrowhead), suggesting fracture. Rudimentary appendicular pectoral skeleton, observing a remnant of the scapulocoracoid process (white lines). Pulmonary fields (arrows) the left pulmonary area is well developed, while the right is rudimentary, or absent. In the cranial and medial aspect of the left lung there is an increase of radiopacity, suggestive of pulmonary contusion and hemorrhage. Rudimentary appendicular pelvic skeleton, observing a trace of the ilio (asterisks). (3) Laterolateral projection of Case 2. Rudimentary appendicular pectoral skeleton (circle). Higher intra luminal radiopacity in cranial segment of trachea (arrowhead). Left pulmonary field with increase of radiopacity in almost all its extension, suggesting severe pulmonary contusion and hemorrhage (arrow). (4) Dorsoventral projection of Case 2. Right temporomandibular luxation with increase of volume and radiopacity of soft tissues (arrows heads). Rudimentary appendicular pectoral skeleton (white lines). Left pulmonary field with increase of radiopacity in almost all its extension, suggesting severe pulmonary contusion and hemorrhage. Note the final portion of the digestive tract with the presence of fecal material and gas (asterisk). (5) Laterolateral projection of Case 3. Loss of definition of cranial segment of trachea, and the presence of areas of radiolucency in soft tissues, suggesting trachea rupture, with air leakage to adjacent tissues, forming an emphysema (white arrow). Presence of complete fracture of the 19th vertebrae in cranial portion of the body, with marked deviation of the axis of the spine (arrowheads). (6) Dorsoventral projection of Case 3. Rudimentary appendicular pectoral skeleton (white lines). Rib fracture (arrow) and complete fracture of the epiphyses of the nineteenth vertebrae (arrowhead). Rudimentary hind limb (portion of the ilium) (asterisk). Fusion of caudal vertebrae (circle). 
left pulmonary area and a rudimentary right pulmonary area (Fig.2). Radiographic changes included a right mandible branch fracture and pulmonary contusion and hemorrhage (Fig.2). In Case 2, there was an increase in radiopacity of the pulmonary fields in almost all its extension, suggesting pulmonary contusion and hemorrhage (Fig.3) and in the skull, a right temporomandibular dislocation was observed (Fig.4). In the images of the third case, it was possible to observe rupture of the trachea and subcutaneous emphysema (Fig.5), in addition to vertebrae and rib fractures (Fig.6).

\section{POST MORTEM EXAMINATION}

External examination and necropsy technique. External examination is an important procedure of any necropsy, and some aspects should be taken into consideration when externally examining an amphisbaenian. As any other reptile, amphisbaenians have their bodies covered by scales. This is important not only for taxonomic purposes of amphisbaenian species, (Kearney 2003) but in Brazil, amphibians of the order Gymnophyona (caecilians) are frequently confused by amphisbaenians or snakes, which can be easily avoided with the external examination of the skin, once caecilians as any other amphibian, do not have scale-covered bodies. Amphisbaenians lack external ears (Wever \& Gans 1972) and have rudimentary eyes (Foureaux et al. 2010). The reduced size of the globe is normal and should not be confused with microphtalmia (Fig.7). It has been suggested that the visual ability of fossorial reptiles is limited to distinguish variations in light intensity, and despite the presence of all cell layers in the retina of amphisbaenians, their lenses have an irregular morphology, which poses as an obstacle for image formation in the retina (Foureaux et al. 2010). During examination of the oral cavity (Fig.8), the integrity of the teeth, tongue, choana and bone structures should be accessed. Amphisbaenians usually feed on invertebrates and even small mammals, and possess strong, recurved teeth and robust jaws. Most amphisbaenians have subpleurodont dentition and replace their teeth throughout life (Jenkins \& Shaw 2020).

Amphisbaenians have pre-cloacal pores (Fig.9) that secrete protein and mucopolysaccharides plugs that are rubbed against the wall of their tunnels and may serve as an important mechanism for intra and interspecific communication (Antoniazzi et al. 1994). These pores are important for systematics, and some amphisbaeniads have sexual dimorphism related to the presence of pre-cloacal pores, however, there is no difference between sexes of Amphisbaena alba regarding pre-cloacal pores and both males and females can display four to 12 of these structures (Jared et al. 1999). All amphisbaenians analyzed in this study displayed eight pre-cloacal pores. As in other reptiles of the Order Squamata, male amphisbaenians have hemipenes (Fig.10).

Due to their tubular morphology (Fig.11), the necropsy technique is similar to the one used for snakes and consists of performing a longitudinal incision from the mental region to the cloaca on dorsal recumbency (Fig.12), and the skin can be easily reflected laterally for observation of the subcutaneous tissues. A. alba lacks a sternum. After removing the skin covering the head, it is possible to observe the well-developed head muscles used by A. alba to dig tunnels underground (Fig.13).

All cases necropsied presented signs of traumatic injuries, mostly blunt force and sharp force trauma. Case 1 had a focally extensive scar on the dorsal surface of the tail, possibly due to an old traumatic injury caused by a sharp object (Fig.14). This amphisbaenian presented multifocal to coalescing hemorrhagic areas throughout the body ranging from $0.1 \mathrm{~mm}$ to $2 \mathrm{~cm}$ in diameter, including the mandibular region. The evaluation of the oral cavity revealed abundant sanguinolent fluid and multifocal hemorrhagic areas (Fig.15), and, during this procedure, it was possible to observe the normal bifurcated tongue (Fig.16).

In Case 3, during the external examination, a complete fracture of the vertebral canal between the cranial and medial segments of the amphisbaenian, was observed. Amphisbaenians have fossorial habits and are hardly ever seen above the ground. However, during the winter season they might seek for preys or warmer areas on the surface. When human interactions occur during this season, intentional traumas might occur, mostly due to the popular misbelief that these reptiles are venomous and could represent a threat to humans (Costa \& Garcia 2019). Human-related problems are still a major issue for the conservation of reptiles, especially the ones with less public appeal, such as snakes and the poorly known amphisbaenians. In one study (Rivas et al. 2014), out of 200 cases of reptiles presented to a wildlife care center, 115 of them were associated to human-related problems and included traumas caused by vehicles, lawn equipment, fish hooks, and also miscellaneous traumas and traumas of unknown origin.

Internal organ examination. At necropsy, it was possible to observe the extension of the fracture, that completely sectioned the vertebral canal, spinal cord, ribs, and partially sectioned the lungs, trachea, and esophagus (Fig.17) of Case 3. Besides superficial areas of hemorrhage, it was also possible to observe a focal punctiform subcutaneous hemorrhage. The area of the skin with the focal hemorrhage covered the ventral surface of the celomic cavity at the level of the liver and lungs. The left lung was diffusely dark red and edematous (Fig.18). In amphisbaenians, the left lung is usually well developed, whereas the right lung may be reduced or absent, depending on the species (Navega-Gonçalves 2009). This pattern is the opposite of most snakes, which usually exhibit a welldeveloped right lung and a reduced or absent left lung (Van Soldt et al. 2015). In all A. alba in this study, the right lung was not observed during necropsy, despite radiographies indicated a right pulmonary field. The heart was pale with evident right and left auricles. In Case 2 it was also possible to observe multifocal to coalescing ruptures of the liver, and the presence of a cruoric blood clot (Fig.19). The gall bladder was replete in Cases 2 and 3. The liver in Case 2 was diffusely yellow (Fig.19) in comparison to the dark brown liver of Case 3 (Fig.20).

Macroscopically, it was not possible to determine the exact region where the esophagus transitions into the stomach, however the latter presented a larger diameter in comparison to the esophagus. The terminal region of the stomach was narrower than the anterior region (Fig.21), and terminates in a pylorus, which delimitates the transition into the small intestine. These findings are in agreement to what has been described for Amphisbaena vermicularis, Anops kingie, Aulura anomala, Bronia bedai, Cercolophia cuiabana, and Leposternon microcephalum (Navega-Gonçalves 2009). 

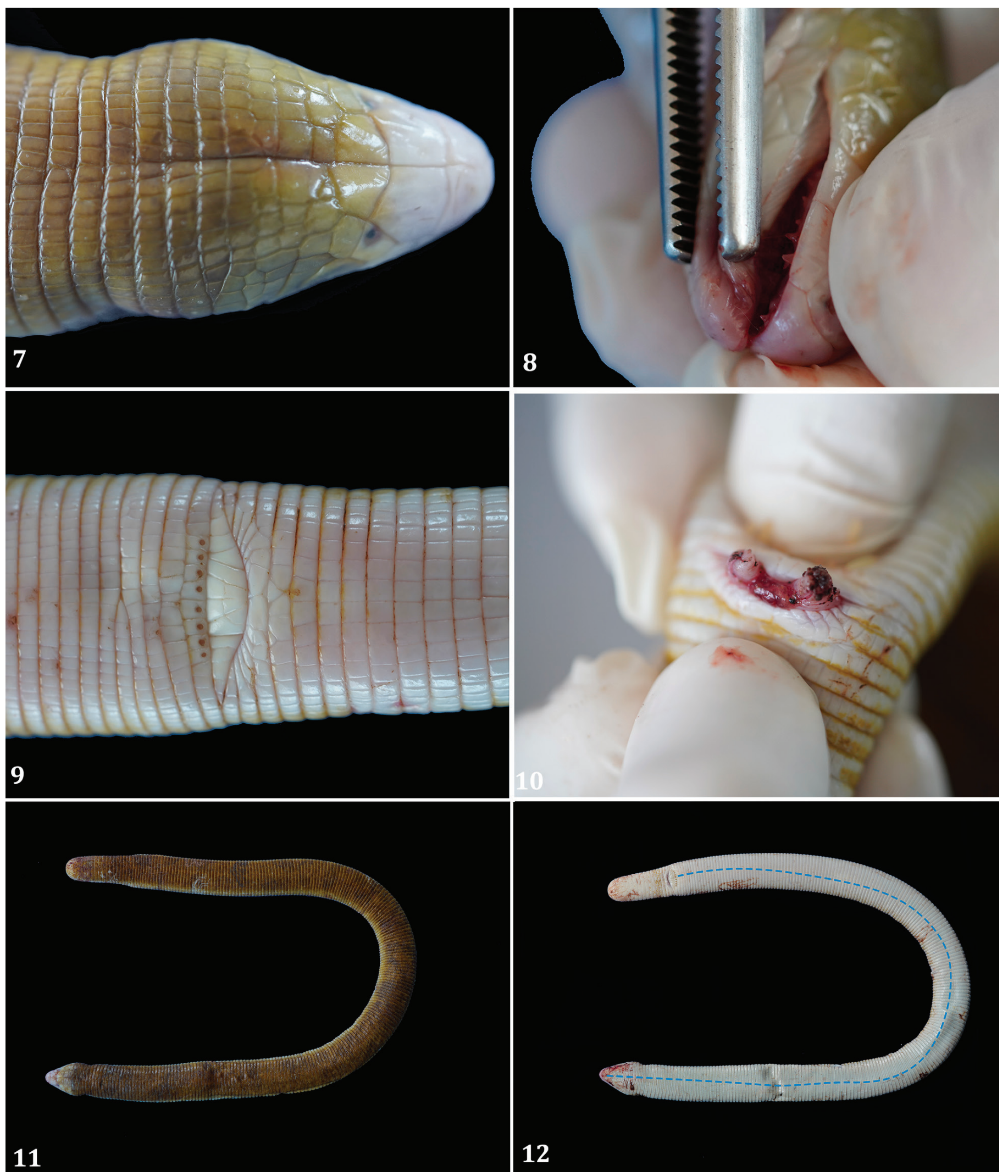

Fig.7-12. External examination of Amphisbaena alba. (7) Dorsal view of the head. The tegument is formed by narrow rings composed by small rectangular scales named "segments". The eyes are approximately $1 \mathrm{~mm}$ wide and are located in the superolateral region of the head (arrowhead). (8) Examination of the oral cavity. Note the dentition. (9) Ventral view highlighting the location of the cloaca (arrow) and precloacal pores (arrowhead). (10) Ventral view of the tail. Examination of the hemipenises. (11) Dorsal view of the whole body. Note the tubular morphology. (12) Ventral view of the whole body. The dashed line indicates the recommended area for incision during necropsy for exposure of the coelom. The incision should start in the mandibular region and extend until the cloaca. 


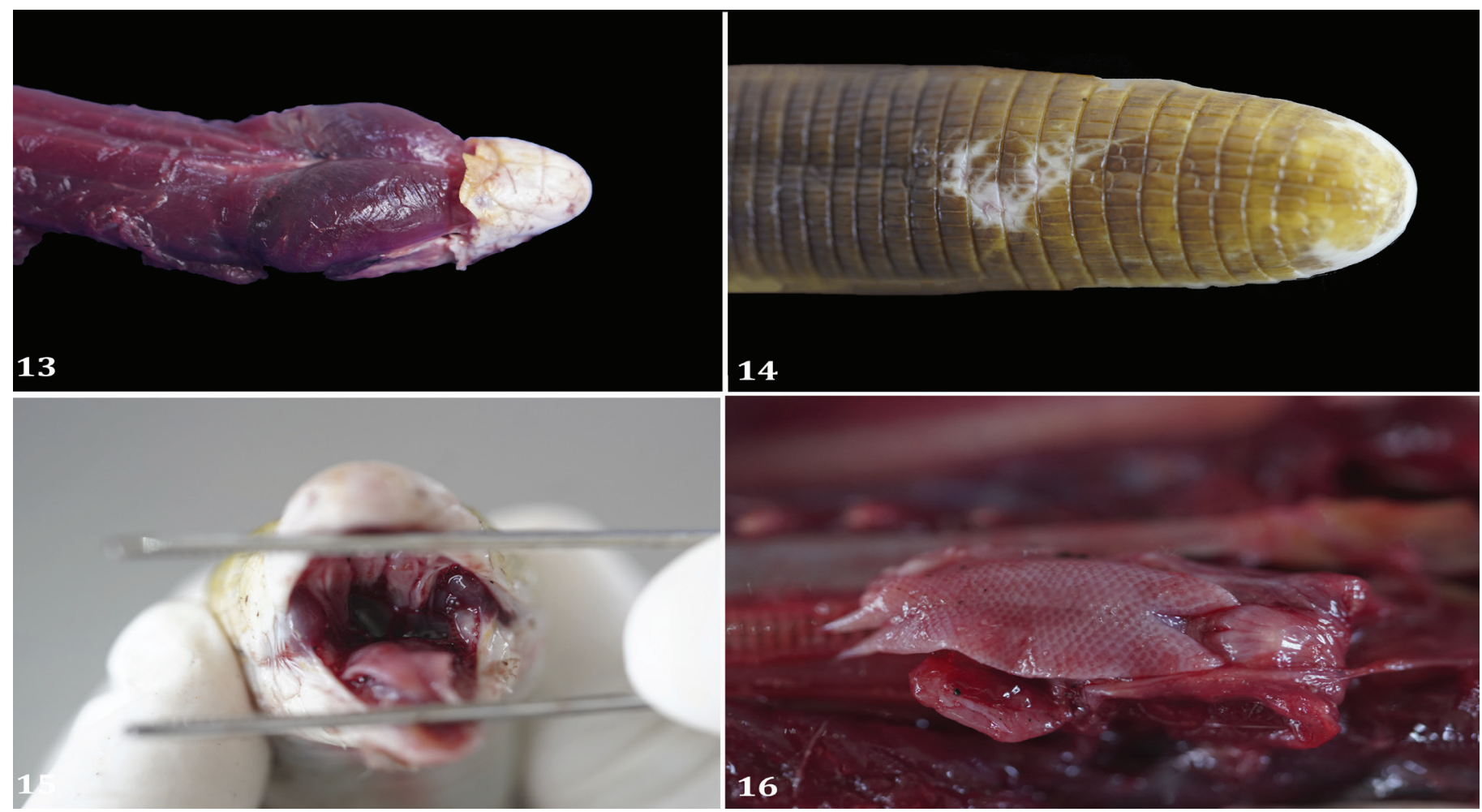

Fig.13-16. Necropsy findings in Amphisbaena alba. (13) Dorsal view of the head. Note the well developed head muscles used for digging tunnels. (14) Dorsal view of the tail. Note the white focal irregular area, presumably a scar from an old traumatic lesion. (15) Oral cavity. Note the sanguinolent content (arrowhead). (16) Normal tongue. Note the bifid partition of the tongue.

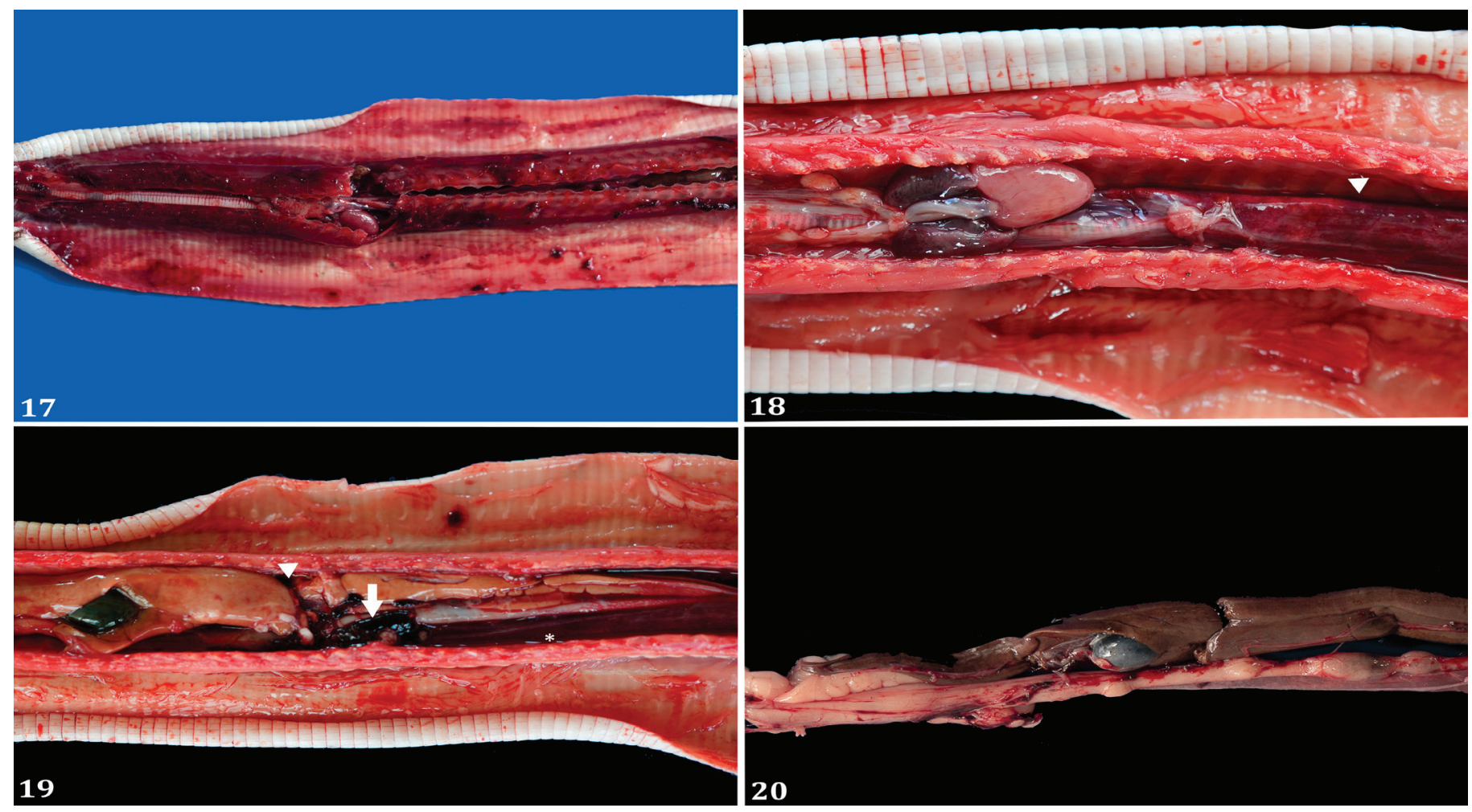

Fig.17-20. Necropsy findings in Amphisbaena alba. (17) Ventral view of the body (Case 3). Opening of the coelomic cavity demonstrates the complete fracture of the vertebral canal and multifocal hemorrhage. (18) Left lung (arrowhead) difusely dark red and shining aspect (edema). (19) Pale yellow liver with focal rupture (arrowhead) and cruoric clot (arrow). Note the difusely dark red lung (asterisk). (20) Normal liver and gall bladder. Note the normal dark brown coloration of the liver. 


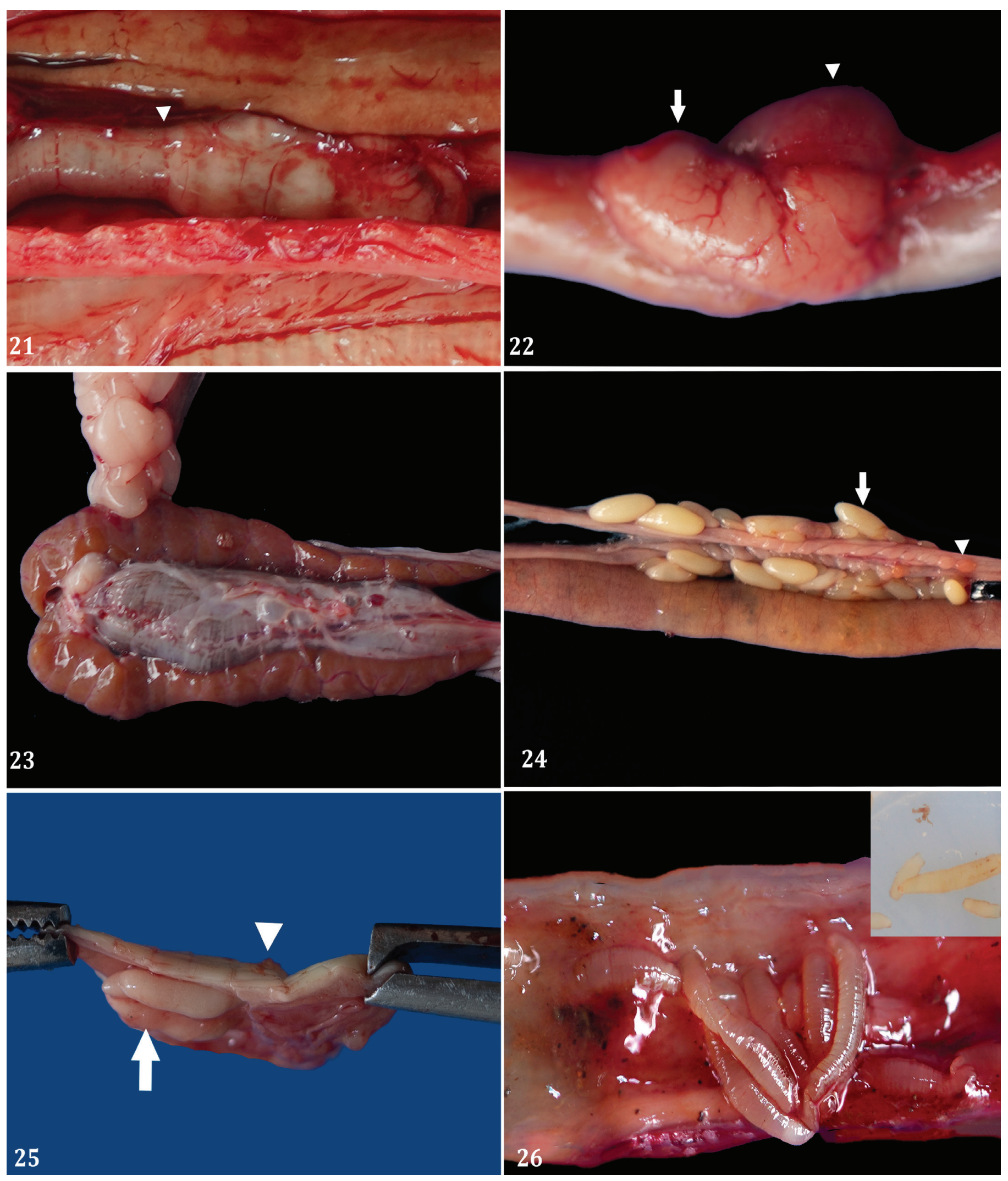

Fig.21-26. Necropsy findings in Amphisbaena alba. (21) Stomach. Note the terminal portion is narrower than the anterior region (arrowhead). (22) Normal spleen (arrowhead) and pancreas (arrow). (23) Normal Kidneys. Note the slightly lobulated appearance of the paired brown kidneys. (24) Ovary. Note the ovaloid shaped egg follicles (Arrow) and the adrenal glands (arrowheads). (25) Longitudinal section of the precloacal pores (arrowhead). Note that the precloacal pores are connected to the glandular bodies (arrow). (26) Large intestine. Note the numerous cestodes (Semenoviella amphisbaenae) attached to the intestinal mucosa. Inset: these helminths presented segmented bodies with calcarious corpuscles. 
The spleen and pancreas of $A$. alba are in close association (Fig.22) and are situated on the right side of the coelomic cavity. The spleen is dark brown to red and lies dorsally on the pancreas, which presents a white to yellowish coloration.

The kidneys were located retroperitoneally in the caudal coelomic cavity, dorsal to the large intestine and were brown, paired, symmetric, elongated and slightly lobulated (Fig.23). Although reported in the literature for Amphisbaena spp. (Holzs 2019), no urinary bladder was observed in all three necropsied amphisbaenians. Out of the three amphisbaenians, two were female and one was male. In the two females, the right ovary was more cranial than the left one and it was composed by several ovaloid light yellow follicles (Fig.24). The adrenal glands were dark yellow and located cranial to the ovaries, with the right one also being more cranial.

On longitudinal section of the pre-cloacal pores, it was possible to see that these structures were connected through a duct to elongated glandular bodies that produce and secrete their protein and mucopolysaccharide plugs (Fig.25).

The mucosa of the large intestine of two of the amphisbaenians in this study was parasitized by flat segmented parasites (Fig.26). These helminths were collected in alcohol-formalin-
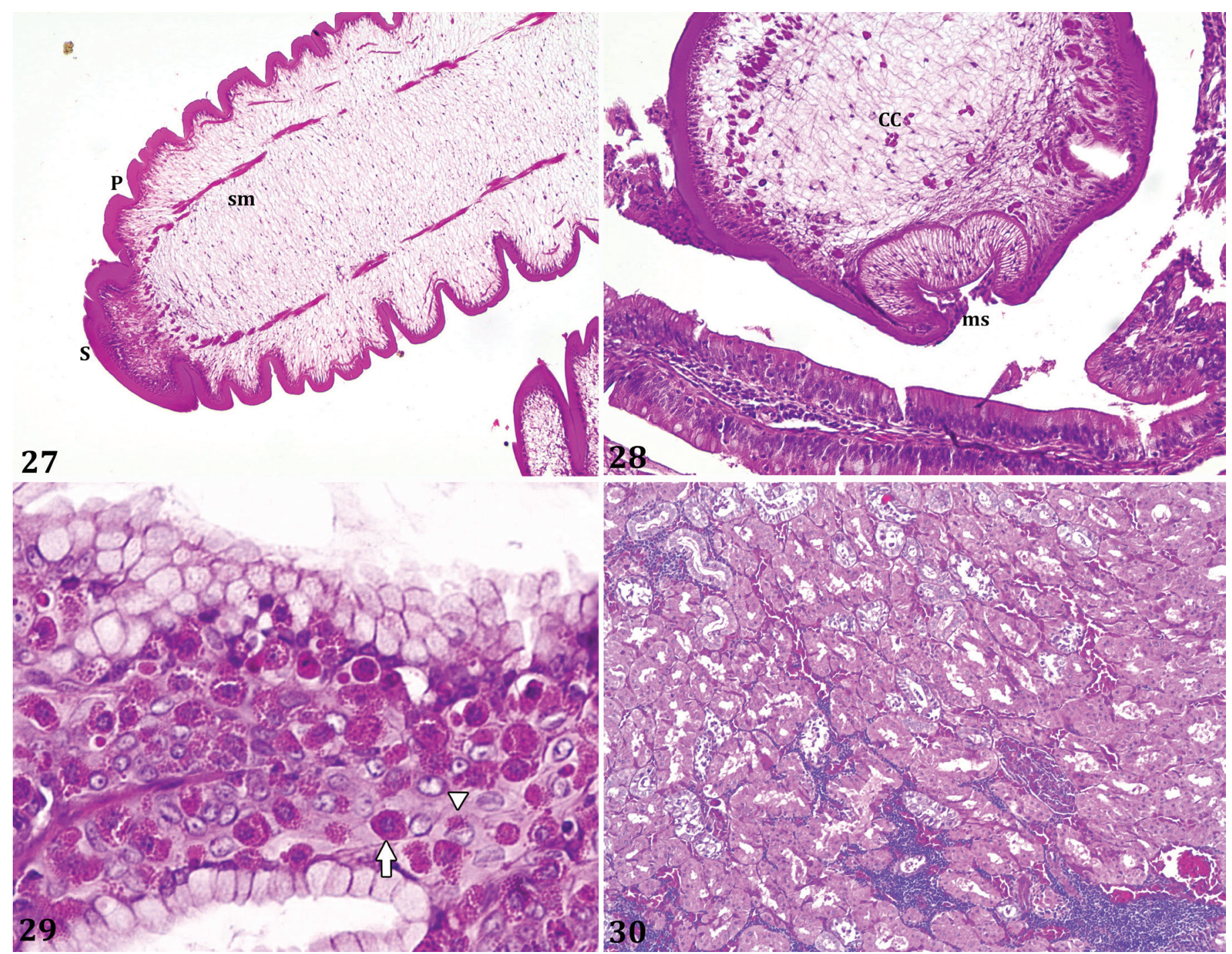

Fig.27-30. Microscopic findings in Amphisbaena alba. (27) Longitudinal section of a cestode (Semenoviella amphisbaenae), Note the presence of the scolex (s) without rostellum and acoels is noted, which is fixed on the mucosa of the small intestine of the host by means of its suction cups. The adult body or strobile is altered by segmentation of proglottids (p) that increase in width as they move away from the scolex. The parenchyma is filled with innumerable branched septa, which assume a spongy appearance, which depart from the integument and are divided into the cortical and medullary region by means of a thin layer of smooth musculature (sm). HE, obj.10x. (28) Cross section of the scolex showing a muscular sucker ( $\mathrm{ms}$ ) characterized by a circular structure composed of muscular fibers in a radial arrangement. In the body parenchyma there are numerous oval and basophilic structures called calcareous corpuscles (cc). Note that in this case, it is possible to observe fragments of the host's small intestine epithelium inserted inside the muscular sucker. HE, obj.20x. (29) A cell type presenting a strongly eosinophilic and granular cytoplasm and central basophilic nucleus, that was interpreted as oxynticopeptic cell (arrow), and a second cell type with pale and heterogenous cytoplasm and a flattened peripheral basophilic nucleus, that was interpreted as clear mucous cell (arrowhead). HE, obj.20x. (30) One of the amphisbaenians presented a multifocal lymphoplasmacytic infiltrate in the renal interstitium and hemorrhage. HE, obj.20x. 
acetic acid (AFA) fixative and were sent to the "Laboratório de Parasitologia" (LAPAR) from "Universidade Federal Rural de Pernambuco" (UFRPE). They were stained with acetic carmine and diaphanized in creosote. Based on the identification keys proposed by Yamaguti (1959) and Schmidt, the helminths were identified as Semenoviella amphisbaenae, cestodes of the family Anoplocephalidae that frequently parasitize Squamate reptiles (Yamaguti 1959, Schmidt 1986). In Brazil, S. amphisbaenae has been reported in the States of Minas Gerais, São Paulo and Pará, usually affecting the small intestines of A. alba and Amphisbaena fuliginosa (Quirino et al. 2018). Important features such as life cycle, geographic distribution and morphologic characteristics are scarce. Cestodes of the family Anoplocephalidae share distinctive features that include flattened body; short scolex devoid of rostellum, hooks, or hooklets in all stages of development and presence of muscular suckers. Similar to other cestodes, S. amphisbaenae lacks a digestive tract.

\section{MICROSCOPIC EVALUATION}

Fragments of all organs were collected in 10\% neutral buffered formalin and processed routinely for histology using hematoxylin and eosin (HE) stain. It was possible to observe several normal features and microscopic lesions in the tissues of Amphisbaena alba. The available literature for histopathology of amphisbaenians is scant, and our results were compared mostly to what is known for other reptile groups. Basic morphological and pathological features of selected tissues are described below.

The histological features of the helminths found in the intestines of two A. alba corroborate with the identification of the cestodes Semenoviella amphisbaenae. The cestodes presented a segmented body divided into proglottids with a thick layered tegument and longitudinal muscles (Fig.27). The scolex lacks a rostellum and hooks, but presents a large muscular sucker, frequently adhered to the epithelial cells of the intestine (Fig.28). There were no inflammatory lesions associated to the cestodes.

Histologically, the fundus-body region of the stomach was composed by gastric glands that housed two main types of cells: a cell type presenting a strongly eosinophilic and granular cytoplasm and central basophilic nucleus, that was interpreted as oxynticopeptic cell, and a second cell type with pale and heterogenous cytoplasm and a flattened peripheral basophilic nucleus, that was interpreted as clear mucous cell (Fig.29). While the clear mucous cells produce mucins that will combine with water to produce a protective gel, the oxynticopeptic cells, also known as dark serous cells, perform the combined functions of chief and parietal cells of mammalians, producing both pepsinogen and hydrochloric acid (Liquori et al. 2000). In one of the amphisbaenians, there were intraluminal nematodes that were not observed macroscopically. No inflammatory lesions were associated with their presence.

In the male amphisbaenian it was possible to observe the sexual segment in the kidney. The sexual segments were distributed in the periphery of the kidneys and were composed by a simple columnar epithelium with secretory granules filling the apical region and the lumen of the sexual segments. The sexual segment is a modification of the kidney ducts of the Squamata reptiles, that is usually only seen in males (Sever et al. 2012). The exact function of the sexual segments in Squamata are still unclear, but it has been hypothesized that they may perform a diverse range of functions including sperm nutrition and activation, plug formation and maintenance of stored sperm (Silva et al. 2019). One of the amphisbaenians presented a multifocal lymphoplasmacytic infiltrate in the renal interstitium and hemorrhage (Fig.30). No apparent cause was evidenced.

Histologically, the left lung displays a cranial faveolar region responsible for gas exchange, and a caudal region devoid of respiratory epithelium. In the cranial region, the pulmonary parenchyma is densely subdivided into trabeculae that originate the faveoli (Fig.31). Thick smooth muscle bundles were observed at the free edge of the interfaveolar walls (Fig.32). Two of the amphisbaenians displayed pulmonary hemorrhage and emphysema, probably associated to the traumatic injuries.

The testis of the male amphisbaenian was comprised of several lobules containing seminiferous tubules. Spermatozoa were seen within the lumen of the seminiferous tubules and spermatogonia were seen along the basement membrane (Fig.33). The hemipenes consisted of a paired erectile body covered by a stratified squamous epithelium underlined by a mesh of connective tissue and smooth muscle (Fig.34). Throughout the erectile body there are several sinusoids intermingled with the connective tissue, which provides the erectile capabilities of the hemipenis.

A longitudinal section of one of the pre-cloacal pores, revealed that the glandular body is formed by conical to elongate lobules divided by collagen septa, and lies adjacent to an elongated secretory duct that connects to the pre-cloacal pore (Fig.35). The glandular body is composed by germinative and secretory cells, with densely packed cytoplasm filled with eosinophilic granules (Fig.36).

\section{CONCLUSIONS}

To the author's knowledge, this is the first study to incorporate morphological, clinical, and pathological aspects of Amphisbaena alba.

The secretive and fossorial habits of the amphisbaenians make it difficult to collect solid data from these species, which makes the available literature about clinical and pathological aspects scarce.

This manuscript brings essential information for wildlife veterinarians and pathologists who may have to treat or perform a necropsy on these unique reptiles.

Acknowledgments.- The authors would like to thank Dr. Jaqueline Bianque de Oliveira's lab at UFRPE for identifying the cestodes found in this study.

Conflict of interest statement.- The authors declare no conflict of interest.

\section{REFERENCES}

Almeida J.P.F.A., Freitas M.A., Silva M.B., Valverde M.C.C., Rodrigues M.T., Pires A.M. \& Mott T. 2018. A new four-pored Amphisbaena (Squamata: Amphisbaenidae) from northeastern Brazil. Zootaxa 4514(4):553-562. <https://dx.doi.org/10.11646/zootaxa.4514.4.8>

Antoniazzi M.M., Jared C. \& Junqueira L.C.U. 1994. Epidermal glands in squamata: fine structure of pre-cloacal glands in Amphisbaena alba (Amphisbaenia, Amphisbaenidae). J. Morphol. 221(1):101-109.<https:// dx.doi.org/10.1002/jmor.1052210108> <PMid:29865377> 

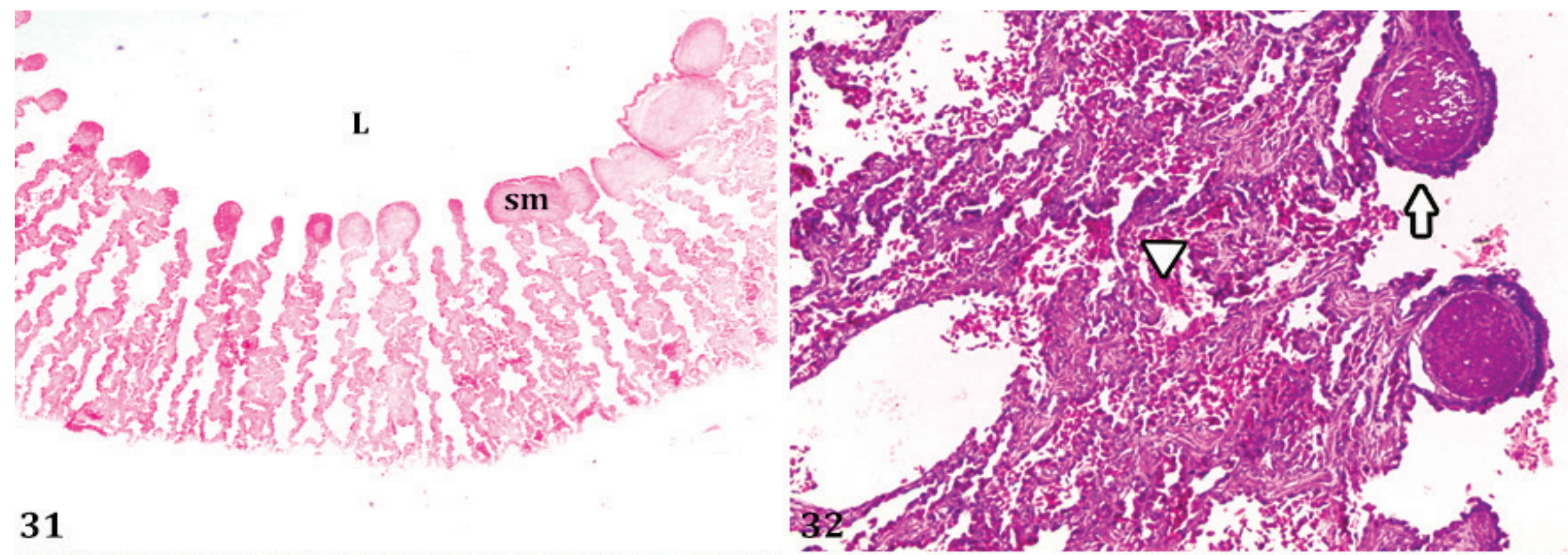

\section{1}

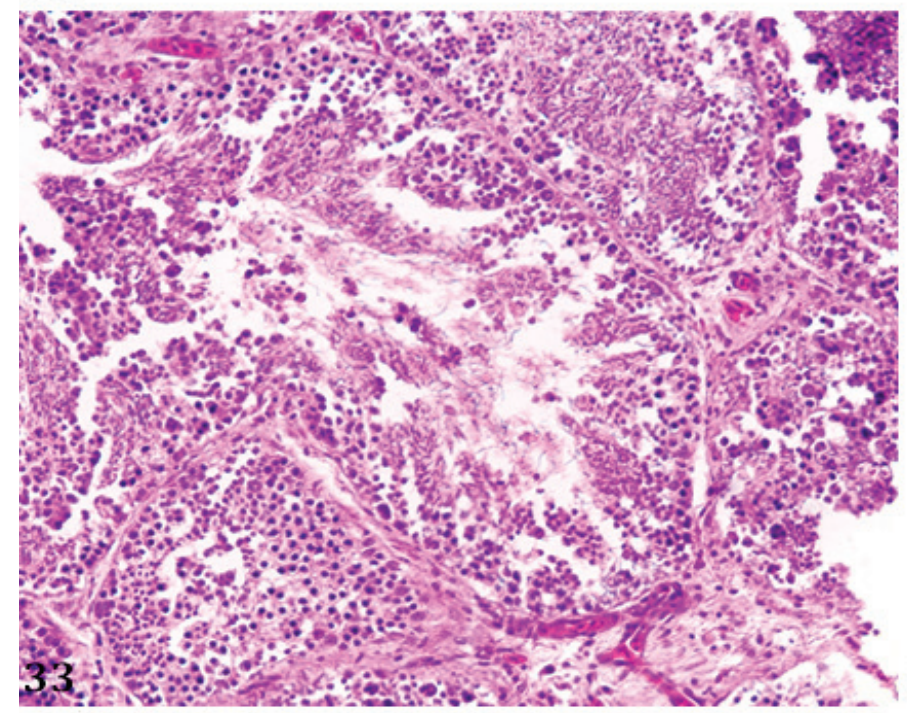

34
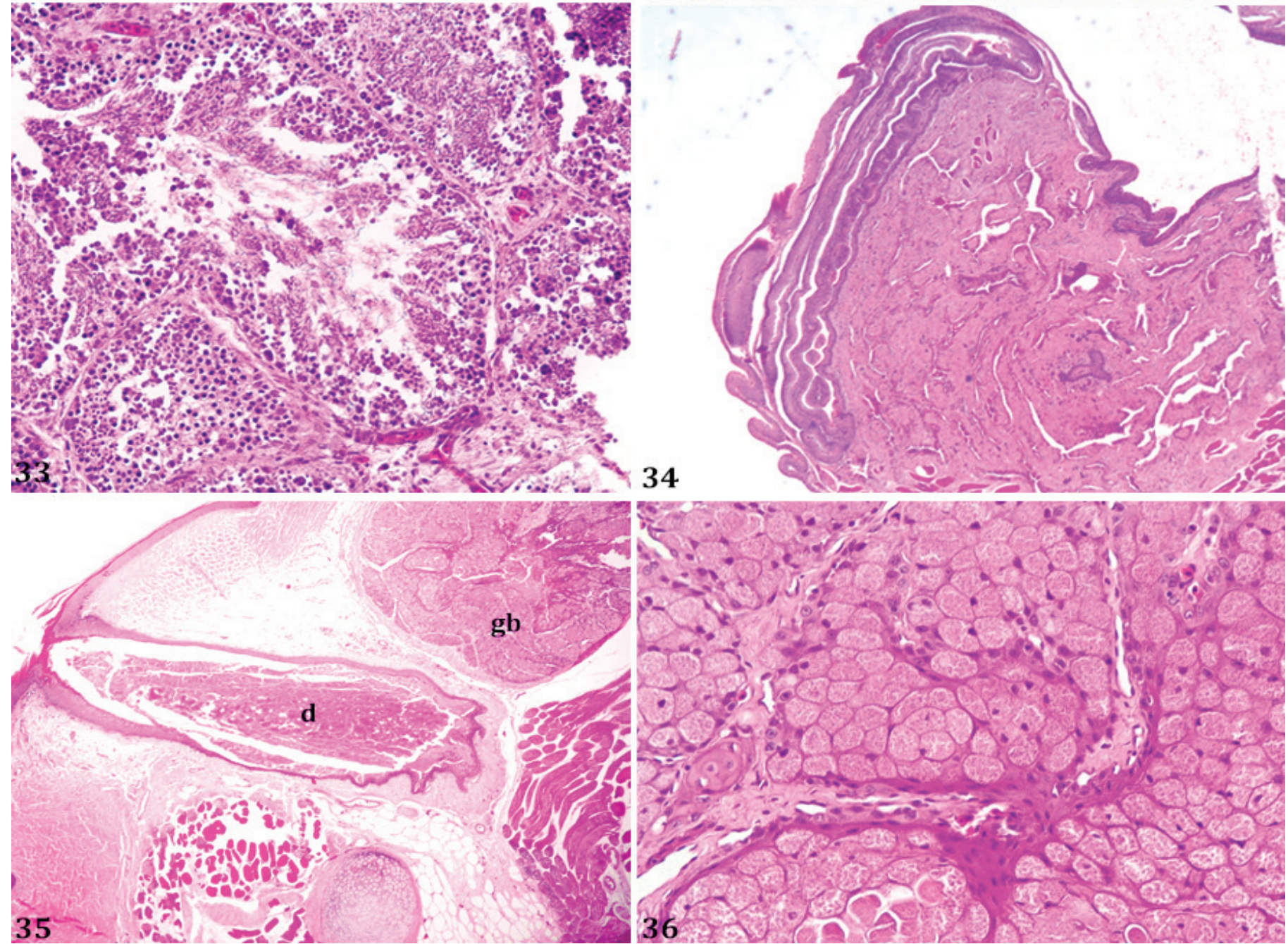

Fig.31-36. Microscopic findings in Amphisbaena alba. (31) Cross section of the lung. An important characteristic of amphisbaena is that they have a tubular looking lung, the smooth muscle $(\mathrm{sm})$ directed to the lumen (l) of the organ can be seen in the image. HE, obj.4x. (32) Lung. It is possible to observe in better detail a well-defined and circumscribed area that indicates the thick bundles of smooth muscle at the edges of the interalveolar walls (arrow). HE, obj.10x. (33) Testis. The parenchyma of the organ is composed of several lobes observing in the lumen of the seminiferous spermatozoid tubes and along the basal membrane, the spermatogonia. HE, obj.20x. (34) Hemipenes. Consists of an erectile body covered by a stratified squamous epithelium that is underlined by a mesh of connective tissue and smooth muscle HE, obj.4x. (35) Longitudinal section of the cloacal pore (cp) showing the duct (d) filled with brittle halocrine secretion, below the dermal layer and parallel to it the glandular body (gb). HE, obj.4x. (36) Cross section of the glandular body of a lobular arrangement composed of cells with peripheral nucleus and broad cytoplasm filled with granular and eosinophilic content (secretion). HE, obj.40x. 
Calixto P.d.O. \& Abrahão Morato S.A. 2017. Herpetofauna recorded by a fauna rescue program in a Caatinga area, Rio Grande do Norte, Brazil. Check List 13(5)647-657. <https://dx.doi.org/10.15560/13.5.647>

Colli G. \& Zamboni D. 1999. Ecology of the Worm-Lizard Amphisbaena alba in the Cerrado of Central Brazil. Copeia 1999(3):733. <https://dx.doi. org/10.2307/1447606>

Costa H.C. \& Bérnils R.S. 2018. Répteis do Brasil e suas unidades federativas: lista de espécies. Herpetol. Bras. 7(1):11-57.

Costa H.C. \& Garcia P.C.A. 2019. Quem são as anfisbênias? Revta Biol. 19(1):1930. <https://dx.doi.org/10.7594/revbio.19.01.03>

Costa H.C., Resende F.C., Teixeira Jr M., Dal Vechio F. \& Clemente C.A. 2015. A new Amphisbaena (Squamata: Amphisbaenidae) from southern Espinhaco Range, southeastern Brazil. An. Acad. Bras. Ciênc. 87(2):891-901. <https:// dx.doi.org/10.1590/0001-3765201520140088>

Foureaux G., Egami M., Jared C., Antoniazzi M., Campos Gutierre R. \& Smith R. 2010. Rudimentary eyes of squamate fossorial reptiles (Amphisbaenia and Serpentes). Anatom. Rec., Hoboken, 293(2):351-357. <https://dx.doi. org/10.1002/ar.21021> <PMid:19899119>

Holzs P.H. 2019. Anatomy and physiology of reptile renal system, p.103-115. In: Pollock C. (Ed.), Renal Disease, an Issue of Veterinary Clinics of North America: exotic animal practice. E-Book. Elsevier Health Sciences.

Jared C., Antoniazzi M.M., Silva J.R. \& Freymuller E. 1999. Epidermal glands in Squamata: microscopical examination of precloacal glands in Amphisbaena alba (Amphisbaenia, Amphisbaenidae). J. Morphol. 241(3):197-206. <https://dx.doi.org/10.1002/(SICI)1097-4687(199909)241:3<197::AIDJMOR2>3.0.CO;2-5>

Jenkins K.M. \& Shaw J.O. 2020. Bite force data suggests relationship between acrodont tooth implantation and strong bite force. PeerJ. 8:e9468. <https:// dx.doi.org/10.7717/peerj.9468><PMid:32656000>

Kearney M. 2002. Appendicular skeleton in Amphisbaenians (Reptilia: Squamata). Copeia, (3):719-738, 720. <https://dx.doi.org/10.1643/00458511(2002)002[0719:ASIARS]2.0.CO;2>

Kearney M. 2003. Systematics of the Amphisbaenia (Lepidosauria: Squamata) based on morphological evidence from recent and fossil forms. Herpetological Monographs, 17(1)1-74. <https://dx.doi.org/10.1655/07331347(2003)017[0001:SOTALB]2.0.CO;2>

Lainson R. 2003. Some coccidial parasites of the lizard Amphisbaena alba (Reptilia: Amphisbaenia: Amphisbaenidae). Mem. Inst. Oswaldo Cruz 98(7):927-936.<https://dx.doi.org/10.1590/S0074-02762003000700012>

Liquori G.E., Ferri D. \& Scillitani G. 2000. Fine structure of the oxynticopeptic cells in the gastric glands of the ruin lizard, Podarcis sicula campestris De Betta, 1857. J. Morphol.243(2):167-171.<https://dx.doi.org/10.1002/(SICI)10974687(200002)243:2<167::AID-JMOR5>3.0.CO;2-G><PMid:10658200>

Navega-Gonçalves M.E.C. 2009. Anatomia visceral comparada de seis espécies de Amphisbaenidae (Squamata: Amphisbaenia). J. Zool., Curitiba, 26(3):511526. <https://dx.doi.org/10.1590/S1984-46702009005000009>

Oliveira E.C.S., Vaz-Silva W., Santos-Jr A.P., Graboski R., Jr Teixeira M., Vechio F.D. \& Ribeiro S. 2018. A new four-pored Amphisbaena Linnaeus, 1758 (Amphisbaenia, Amphisbaenidae) from Brazilian Amazon. Zootaxa 4420(4):451-474. <https://dx.doi.org/10.11646/zootaxa.4420.4.1> $<$ PMid:30313519>

Pinna P.H., Mendonça A.F., Bocchiglieri A. \& Fernandes D.S. 2010. A new two-pored Amphisbaena Linnaeus from the endangered Brazilian Cerrado biome (Squamata: Amphisbaenidae). Zootaxa (2569):44-54. <https:// dx.doi.org/10.5281/zenodo.197346>

Pinna P.H., Mendonça A.F., Bocchiglieri A. \& Fernandes D.S. 2014. A new species of Amphisbaena Linnaeus, 1758 from a Cerrado Region in Bahia, Northeastern Brazil (Squamata: Amphisbaenidae). Herpetologica 70(3):339349. <https://dx.doi.org/10.1655/HERPETOLOGICA-D-13-00039>

Quirino T.F., Ferreira A., Silva M.C., Silva R.J., Morais D.H. \& Avila R.W. 2018. New records of helminths in reptiles from five states of Brazil. Braz. J. Biol. 78(4):750-754. <https://dx.doi.org/10.1590/1519-6984.175745>
Ribeiro L., Gomides S. \& Costa H. 2018. A new species of Amphisbaena from Northeastern Brazil (Squamata: Amphisbaenidae). J. Herpetol. 52(2):234241. <https://dx.doi.org/10.1670/17-028>

Ribeiro S., Gomes J.O., Silva H.L.R., Cintra C.E.D. \& Jr Silva N.J. 2016. A new two-pored species of Amphisbaena (Squamata, Amphisbaenidae) from the Brazilian Cerrado, with a key to the two-pored species of Amphisbaena. Zootaxa 4147(2):124-142.<https://dx.doi.org/10.11646/zootaxa.4147.2.2> <PMid:27515611>

Ribeiro S., Nogueira C., Cintra C.E.D., Da Silva N.J. \& Zaher H. 2011. Description of a new pored Leposternon (Squamata, Amphisbaenidae) from the Brazilian Cerrado. S. Am. J. Herpetol. 6(3):177-188. <https://dx.doi. org/10.2994/057.006.0303>

Ribeiro S., Sa V., Santos-Jr A.P., Graboski R., Zaher H., Guedes A.G., Andrade S.P. \& Vaz-Silva W. 2019. A new species of the Amphisbaena (Squamata, Amphisbaenidae) from the Brazilian Cerrado with a key for the twopored species. Zootaxa 4550(3):301-320. <https://dx.doi.org/10.11646/ zootaxa.4550.3.1>

Ribeiro S., Santos Junior A.P. \& Zaher H. 2015. A new species of Leposternon Wagler, 1824 (Squamata, Amphisbaenia) from northeastern Argentina. Zootaxa 4034(2):309-324.<https://dx.doi.org/10.11646/zootaxa.4034.2.4> $<$ PMid:26624443>

Rivas A.E., Allender M.C., Mitchell M. \& Whittington J.K. 2014. Morbidity and mortality in reptiles presented to a wildlife care facility in Central Illinois. Human-Wildlife Interactions 8(1):78-87. <https://dx.doi. org/10.26077/34wh-vh39>

Roberto I.J., Brito L.B. \& Avila R.W. 2014. A new six-pored Amphisbaena (Squamata: Amphisbaenidae) from the coastal zone of northeast Brazil. Zootaxa 3753:167-176. <https://dx.doi.org/10.11646/zootaxa.3753.2.6> <PMid:24872288>

Schmidt G.D. 1986. Handbook of Tapeworm Identification. CRC Press, Florida. 688p.

Sever D.M., Rheubert J.L., Gautreaux J., Hill T.G. \& Freeborn L.R. 2012. Observations on the sexual segment of the kidney of snakes with emphasis on ultrastructure in the yellow-bellied sea snake, Pelamis platurus. Anat. Rec., Hoboken, 295(5):872-885. <https://dx.doi.org/10.1002/ar.22435> <PMid:22396145>

Silva K.P.M., Silva K.B., Sueiro L.R., Oliveira M.E.E.S. \& Almeida-Santos S.M. 2019. Reproductive biology of Bothrops atrox (Serpentes, Viperidae, Crotalinae) from the Brazilian Amazon. Herpetologica 75(3):198-207. $<$ https://dx.doi.org/10.1655/D-18-00023>

Teixeira Junior M., Vechio F.D., Mollo Neto A.M. \& Rodrigues M.T. 2014. A new two-pored Amphisbaena Linnaeus, 1758, from Western Amazonia, Brazil (Amphisbaenia: Reptilia). S. Am. J. Herpetol. 9(1):62-74. <https:// dx.doi.org/10.2994/SAJH-D-14-00004.1>

Teixeira Junior M., Vechio F.D., Recoder R., Cassimiro J., De Sena M.A. \& Rodrigues M.T. 2019. Two new highland species of Amphisbaena Linnaeus, 1758 (Amphisbaenia, Amphisbaenidae) from Bahia State, Brazil. S. Am. J. Herpetol. 14(3):213-232. <https://dx.doi.org/10.2994/SAJH-D-17-00097.1>

Van Soldt B.J., Metscher B.D., Poelmann R.E., Vervust B., Vonk F.J., Müller G.B. \& Richardson M.K. 2015. Heterochrony and early left-right asymmetry in the development of the cardiorespiratory system of snakes. PLoS One 10(1):e116416. <https://dx.doi.org/10.1371/journal.pone.0116416> $<$ PMid:25555231>

Westphal N., Mahlow K., Head J.J. \& Müller J. 2019. Pectoral myology of limbreduced worm lizards (Squamata, Amphisbaenia) suggests decoupling of the musculoskeletal system during the evolution of body elongation. BMC Evol. Biol. 19(1):16. <https://dx.doi.org/10.1186/s12862-018-1303-1> $<$ PMid:30630409>

Wever E.G. \& Gans C. 1972. The ear and hearing in Bipes biporus. Proc. Natl Acad. Sci. USA 69(9):2714-2716. <https://dx.doi.org/10.1073/pnas.69.9.2714>

Yamaguti S. 1959. Systema Helminthum: the cestodes of vertebrates. Vol.2 Interscience Publishers, London. 868p. 